\title{
AN OPINION SURVEY ON ISSUES OF PROVISION AND MANAGEMENT OF ADULT LITERACY PROGRAMME IN NIGERIA: IMPLICATIONS FOR PLANNING
}

\section{AKINSOLU, ABIODUN OLATOUN Ph.D.}

\begin{abstract}
There are almost 800 millions illiterate adults worldwide (UNESCO, 2005\%. Based on the above. the're is an urgen need to expand the vision of both the MDGs to capture education for adult. so as to achieve the widespread agreement that through adult basic education and literacy intervention, human and social development can be enhanced (UNDP, 1997).This paper therefore examines issues in the provision and management of adult literacy programme in Nigeria through a descriptive suney analysis of ex- post facro. Guided by + Research questions and I hypothesis, findings revealed the perceptions of beneficiaries in respect of this programme. The paper concludes that the successful implementation of adult literacy programme is the only way of ensuring sustainable development in the country because it is only a man that can distinguish between truth anc' falsehood. He is really free to choose and participate actively in promoting socio, economic and political development of his/her conntry while the planning implications nere likestise highlighted.
\end{abstract}

Key words: Issues, Provision, Management and Adult Literacy

\section{Introduction}

Educational achievement and attainment of any given country in obtaining national development and performance hinged on rating the performance of the lowest achievers and of those with lowest 'level of qualifications. These are the groups whose improvement will make the greatest difference to the national average (David and Richard, 2006). This implies the need to identify these groups for proper mainstreaming. Basic skills education for youth and adults is crucial to a robust pipeline leading to socio- economic development. (NCAL and ILI. 2006). Literacy is il vilal atsel and key component of skilk development.
Globally, there are nearly one billion adults who cannot read and write. according to UNESCO statistics (UNESCO, 2010). Therefore many countries have decided to come up with policies that specifically target low achievers and those with few formal qualifications, youth who have dropped out of the school and low skilled adults. This confirms UNESCO (2005) in their report titled "Writing the wrong" that all governments worldwide have signed up to a UN goal that promises a $50 \%$ reduction in illiteracy by 2015 . Progress towards the target of halving illiteracy has been painfully slow. On current trends. the world will be less than

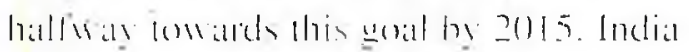


alone will have a shortfall of some 81 million literate people.

There have been some encouraging developments in recent years. Several countries with large numbers of illiterate adults are increasing investment in national literacy programmes, Nigeria inclusive. The Literate Brazil Programme, which started in 2003, is an example: it has reached 8 million learners. India is reconfiguring and expanding its national literacy programme to focus more strongly on women, low-caste groups and minorities. Burkina Faso's national education strategy has scaled up investment in literacy from $1 \%$ to $7 \%$ of the education budget. Governments and donors need to learn from emerging models of good practice and act with greater resolve in prioritizing literacy within wider education strategies.

Osuji. (2006) opined that the issue of adult education concerns the illiterates who have never been to school and different completers of the formal education at different levels. He defined adult education as any education programme designed for people regarded as adults in their communities. That is, designed for people who are mentally mature and are socially responsible. For the illiterates, literacy education is designed so as to afford them some development for self fulfillment through attainment of literacy skill.
As noted by Faure, et al (1972: 141) in Osuji. (2006) literacy training should form an integral part of any development undertaking to help man to become a conscious agent and master of himself. Functional literacy aims at developing individuals' mental equipment and communicative powers, as well as their technical and vocational capacities. It offers educative functions to broad sectors of society, promotes the formative part, which the major economic activities may play. Thus, literacy education is a great means of integrating the illiterates with the communities of the literate world thereby helping them to communicate with both the living and the dead resulting in their attainment of selffulfillment.

The need to focus on these groups is to improve overall educational programme in all developing countries through raising the skills of the existing workforce, in order to make all these country to compete in the global economy thus having a multiplier effect on the socio- political development of the country. The issue of literacy should not be treated with levity by any given government because it is a social tool for political, economic and social development of any given society. No wonder Ukeje (1978) reported that "a man who cannot distinguish between right and wrong no doubt can be a best player of his/her citizenship. 


\section{Statement of the Problem}

UNESCO, (2009) reports that one in five adults worldwide was still illiterate. According to the report. over 776 million adults worldwide are still illiterate. twothird of who are women. while about 75 million children are out of school with very high drop-out rates. Action Aid (2012) likewise opined that it is unfortunate that government is not taking the delivery of adult literacy very seriously in Nigeria. Both states and national government are not investing in adult literacy. All emphases are laid on formal education. According to the report, issues concerning adult literacy are ignored under the guise of Universal Basic Education (UBE) which has no provision for adult literacy. They have failed to recognize that more than 30 per cent of Nigerians wallow in illiteracy and these group of people have a right to access education.

According to the UNDP Human development Report of 2007 / 2008 as cited in UNESCO, GMR, (2009), Nigeria sill rates very low in human development assessment. The report states that 69.1 per cent adult Nigerians are illiterate. Nigeria is a country of high illiteracy rate. A proof of this is her ranking among nine countries with the highest population of illiterates in the world. The group, otherwise known as the E9 Countries. comprises of Bangladesh, Brazil, China, Egypt, India. Indonesia, Mexico, Nigeria and Pakistan. These nations also account for more than 50 per cent of the world's population.
The idea of Nigeria supporting literacy education in four other countries is a case of a blind man leading a blind man as opined by Noboh. (2009).

The current national literacy rate in Nigeria is $54 \%$ which is far below the expected average of $57 \%$ for subSaharan African. Some other national examples are Cameron $79 \%$ and Ghana $68 \%$ with female literacy being lower in Nigeria than all these countries mentioned. The above culminated into sharp response by Nigerian government. thus leading to the establishment of nonformal education and its placement in the National Policy on Education (NPE) with its policy thrusts aiming to provide functional literacy and continuing education for adults and youths who have never attended school or did not complete their primary education.

This policy thrusts specified the following

Mass literacy, adult and non-formal education policy thrust as stated in section 6, page 25 of the NPE (2006) states that:

- Mass literacy, adult and nonformal education encourages all forms of functional education given to youths and adults outside the formal school system.

The goals of Mass literacy, adult and non-formal education shall be to:

- Provide functional literacy and continuing education for adults and youths who have never had the advantage of formal 
education or who did not complete their primary education, These include the nomads, migrant families, the disabled and other categories or groups. especially the disadvantaged gender.

- Provide functional and remedial education for those young people who did not complete secondary education.

- Provide education for different categories of completers of the formal education system in order to improve their basic knowledge and skills.

- Provide in-service, on-the-job, vocational and professional training for different categories of workers and professionals in order to improve their skills; and

- Give the adult citizens of the country necessary aesthetic cultural and civic education for public enlightenment (FGN. 2006).

Based on the above policy thrusts, Nigeria government have the lead responsibility in meeting the right to adult literacy and in providing leadership, policy frameworks, an enabling environment and resources towards the attainment of all these stated policy thrusts. Part of government effort in ensuring the above stated policy thrust for mass literacy is the establishment of the National Commission for Mass literacy. Adult and Non- formal education. as a parastatal in the Federal
Ministry of Education through Decree No 17 in the year 1990 (Adesina,2005). This was in response to the declaration of Education for All (EFA) goals made in Jomtien. Thailand in March. 1990. The Commission was inaugurated on July 5. 1991 and was given the mandate to address issues of illiteracy amongst adults and the youths. This includes the vulnerable groups such as migrant fishermen. out-of-school children, as well as girls and women, like the Lumina Foundation for Education, in Europe supporting the National Center on Adult Literacy (NCAL) helping in addressing social and economic challenge through an initiative called Learning Connections.

This commission is charged to monitor and coordinate activities relating to mass literacy campaign in order to ensure the success eradication of illiteracy in Nigeria, monitor and coordinate the implementation of all activities for the eradication of illiteracy in Africa. and ensure the collection and dissemination of information on literacy implementation in the continent, conducting researches such as curriculum development, learning and teaching methodologies, appropriate education technologies and needs assessment, the commission as well is to pilot projects in mass literacy, adult and non- formal education in Nigeria.

The present scenario of mass literacy programme most especially the adult literacy programme reveals that there is 
much to be desired because there is still a wide gap between the expected and the actual deliverables of mass literacy programmes in Nigeria therefore this paper tries to examine some prevailing issues which impair effective delivery of this programme through an opinion survey.

\section{THEORETICAL FRAMEWORK}

The theoretical framework of the paper rest on the premise of system theory in management with particular reference to an open system A system is a set of things that affect one another within an environment while in an open system, information receives is being used to interact dynamically with its environment (Midgley, 2003). Based on this, there exists a symbiotic relationship between literacy and socio-economic and political development of any given country. Countries with lower levels of literacy have lower economic growth and lower GDP per capital (Scultz, 1993).

At the moment, Nigeria has over 50 million illiterate citizens. There is no gain saying that this has impacted negatively on all the facets of her developmental efforts and goals. Analysts have argued that the problem of militancy in the Niger Delta region, prostitution, child trafficking, and terrorism by Boko Haram in the Northern region of the country, are all consequences of the growing illiteracy level across the country (Noboh, 2012 in Nigeria Blueprint media). High rate of illiteracy in a given country thus limits the impact of programmes designed to boost livelihoods, protects the environment, deliver clean water, promote participation and democracy and as well fight killer diseases. The figure below illustrates the interrelatedness of literacy programme and socio- economic and political development. 


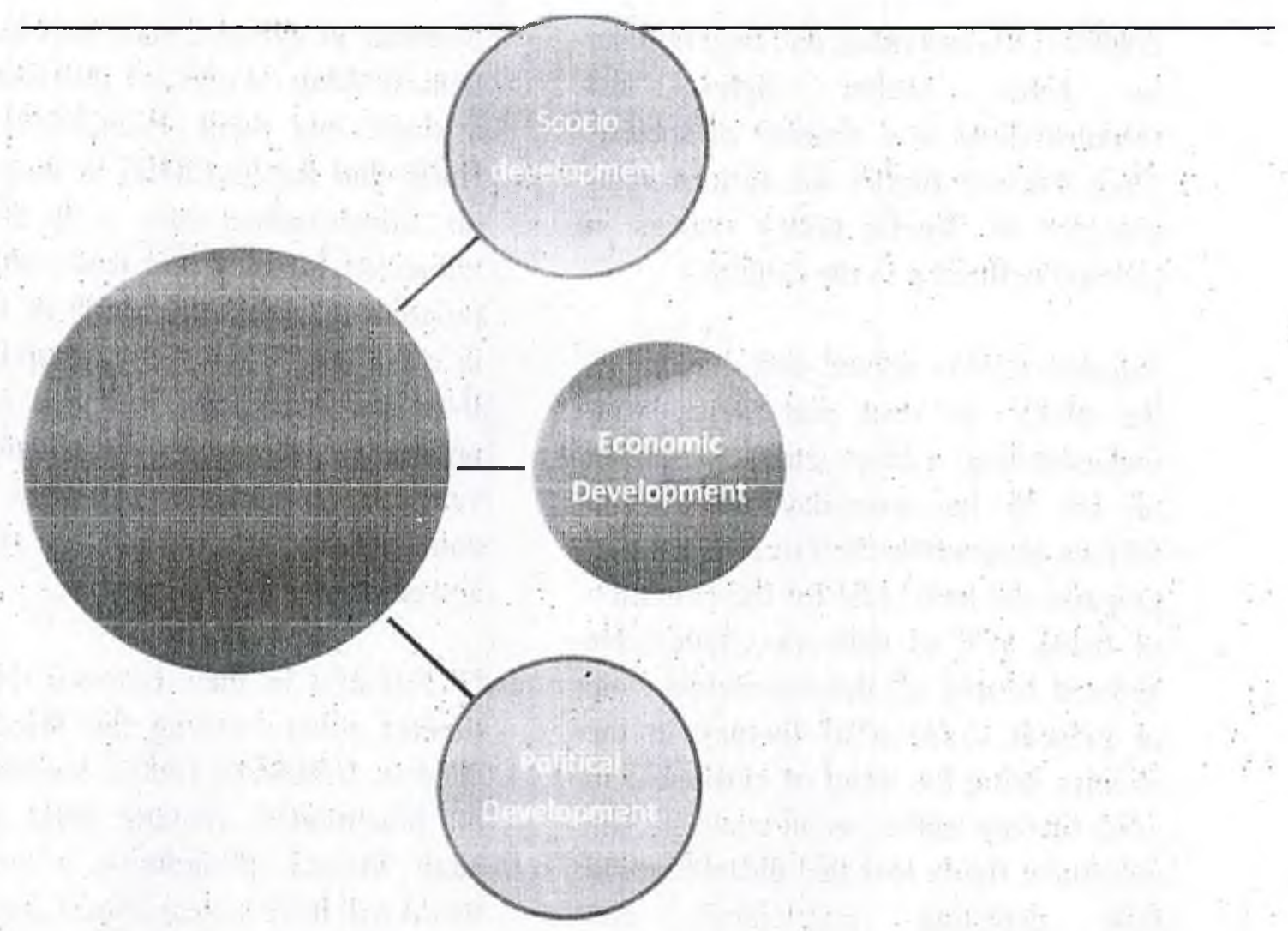

Fig.1 Interrelatedness of Literacy Programme and Socio- Economic \& Political Development

Source: Author, 2012

Fig.1 illustrates the interrelatedness of Literacy Programme and SocioEconomic \& Political Development. It potrays that literacy promotes socioeconomic and political development of any given country because it is only a man that can distinguish between truth and falsehood. He is really free to choose and participate actively in any national development programmes. This makes the role of adult literacy crucial in enlightening and informing societal members in making wise choices both for their individual welfare and for the welfare of the state and the nation respectively.

\section{Literature Review}

Defining literacy is difficult. Scholars do not have an agreed definition. Niranthar as cited in UNESC and FFA rinbal Monitoring Repo ies literacy as a socis $\quad$ in social, cultural $e \quad$ zal power relations. Literacy nous the possibility of enabling transformatory 1 empowering processes which any government must not toy with. Robinson, (2005), and Obanya, (2008) likewise defines literacy as the ability to function in society with the reading. writing and general knowledge skills that 
empower the individual and help him/her to know his/her rights and responsibilities as a member of society. They stressed further on various roles expected of Nigeria policy makers in promoting literacy in the country.

Adesina (2005) opined that literacy is the ability to read and write, with understanding, a short simple statement on his or her everyday life. While literacy programme therefore is one that prepares the individual for the condition of being able to read and writes. He stressed further on the worrisome state of present situation of literacy in the country using the trend of enrolment in adult literacy centres as an analogy. The enrolment figure revealed unstable trend thus depicting inefficiency and ineffective service provision of the programme in Nigeria.

In a study conducted by UNESCO, and EFA Global Monitoring Report of (2009) on people's understanding on the conception of literacy, out of 32 respondents, 29 people supported the statement that literacy is the application of necessary skills in a variety of developmental contexts. From all these definitions, literacy should be seen as a continuous process that requires sustained learning and practice.

No wonder, Cameron, (2005) opined that there are no magic lines to cross from illiteracy into literacy. All policies and programmes should be designed to encourage sustained participation and celebrate progressive achievement rather than focusing on one- off provision with a single end point. Brunchfield, Hua, Hurry and Rocha (2002) in their study on "Longititudinal study of the effect of integrated Literacy and basic education progress on the participation of women in social and economic development in Bolivia" reported that literacy programme embodies acquisition of values, techniques, attitudes and competencies towards socio- political and economic development.

GCE,(2005) in their research on adult literacy titled "writing the Wrong" as cited in UNESCO, (2005) reported that all practitioners running good quality adult literacy programme around the world will have a clear impact across the fill MDGs agenda because adult literacy though not on MDG itself, provides an invisible glue for achieving all the MDGs.

Fasih. (2008): Kinsella and Hua. (2009) in EFA, GMR, (2010) commended that youth and adult illiteracy is the price people and countries are paying for the past failures of education systems. When people emerge from their school years lacking basic reading, writing and numeracy skills, they face a lifetime of disadvantage as illiteracy diminishes their social and economic prospects and damages self-esteem. But the consequences of illiteracy extend beyond the, individual. When people lack literacy, society as a whole suffers from lost opportunities for higher 
productivity, shared prosperity and political participation. Beyond the individual and social costs, illiteracy is a violation of human rights and a global blight on the human condition (Maddox. 2008: Oxenham. 2008). Eradicating it. is one of the most urgent development challenges of the twenty-first century.

ESA, (2005) study report revealed the state of inefficiency of adult literacy programmes in Nigeria. According to Oyedeji (1998) efficiency is the diligent application of economic use of resources, which has tremendous impact on effectiveness of any educational programmes. In a system where the economic resources usage has not yielded desirable results/outcomes such system is reported as an inefficient system. From ESA, (2005), the inefficiency /ineffective of the programme can be attributed to the following: lack of access. poor remuneration of instructors/facilitators. as well as weak monitoring and evaluation thus resulting into economic wastage of government investment.

Adeboyeje, (1994) reported on facilities such as desks, fans, and libraries provision in both formal and non-formal sector of the education system that they are not always adequate. The above situation affects the effective delivery of any educational programme since physical facilities plays vital role in teaching and learning process. In corroborating with Adeboyeje. Kennedy, (2001): UNESCO (1989) and Moore.
(1998) stressed the importance of physical facilities in any educational system as the livewire of education service delivery without which there cannot be effective teaching and learning.

Noboh. (2012) in Nigeria Blueprint Media. reported on the state of funding of adult literacy programmes in the country has been unsatisfactorily. According to them funding has always been a major constraint to the performance of NMEC which virtually affects effective operations of all the adult literacy centres. It was observed that the general funding for adult education sub-sector is relatively marginal and inadequate and the little that the government provides for adult education is hardly released, which suggests that adult education funding is virtually seen as an optional. For 2012, only a paltry $\$ 82$ million was proposed for the commission in the national budget and as it stands, the Mass Literacy and Non-formal Education does not benefit from the 2 per cent consolidated fund meant for basic education. The argument against NMEC is that it is not captured in the UBEC Act as part of the beneficiaries in the UBEC largesse.

Osuji, (2006) in his study on Education for Fullness: The Role of Adult Education in Nigeria in the 21st Century described the role of adult education as complementary or supplementary. Adult education plays a complementary role because it stabilizes one's educational 
attainment as it provides constant refinement of kni,wledge and skills. On the other hand, it plays a supplementary role as it takes over from where the formal system stops. According to him, the formal system takes care of the youth in the perspective of the apprenticeship model of education, that is, education for preparing the youth for a working adult life. But adult education takes care of a person's whole life. It caters for educational aspirations of every adult at any point in time.

Adesuyi, Bolarin, Obanyi and Uyanwa (2007) conducted a study on factors influencing adult learners' participation in literacy programmes in Nigeria. Findings from their study revealed various reasons for adult participation in literacy programmes in Nigeria with particular reference to Atiba Community in Oyo State. The prevailing factors were identified to be: quest for knowledge, ability to read and write, ego boosting. peer pressure, getting government jobs and ability to speak English language.

\section{Methodology}

This article is a descriptive survey study on issues in the provision and management of adult literacy programme in Nigeria with attempts to appraise its implications for planning in ensuring effective delivery of the programme in Nigeria.

\section{Population and sample}

All mass literacy centres in six geopolitical zones of the country serves as the main population for the study. Out of these six zones, four geopolitical zones were sampled purposively using a state each from each zones based on availability of data for situational assessment/appraisal. From these four geo-political zones 300 hundred adult learners of the Adult Literacy Programme were sampled using stratified random sampling based on sex stratum.

\section{Instrumentation}

Desk review / analysis of Documentation guided the study as well as an instrument tagged "Issues in the provision and Management of Literacy Programme in Nigeria" which was developed in order to ascertain most prevailing issues as regards the provision and management of adult literacy programme in Nigeria. Content and face validity of the instrument was established using test construction experts while test re- test was used to ascertain its reliability within 3 weeks interval. This gives a reliability coefficient of $0.81 \%$ which thus makes the instrument highly reliable.

\section{Research Questions}

The study was guided by four research questions: 
1) What is the present state of literacy programme in Nigeria?

2) What is the trend of enrolment in respect to adult literacy centres in Nigeria?

3) What is the rate of female / male participation in adult literacy programme in Nigeria?

4) What is the adult Learners perception of existing issues in the provision and management of adult literacy programmes in Nigeria?

\section{Research Hypothesis}

1) There is no significant difference between the perception of male and female recipients on adult programme

\section{Data collection and analysis}

Both qualitative and quantitative data were collected, appraised and analysed through desk review of some NMEC. And sampled states' documents were appraised and analysed as well as the questionnaire. Descriptive statistics(percentages) was mainly used for the analysis of respondents to the questionnaire while T.test of inferential statistics was used to analyse the difference between male and female adult learners' perceptions.

\section{Findings and Discussions}

Research Question 1: What is the present state of literacy programme in Nigeria?

\section{Literacy Situational Analysis in Nigeria}

With an average rate of $54 \%$, Nigeria is ranked as one of the low literacy countries of the world. The situation report of literacy in the country depicts that the overall progress being made is still low. According to National Population Commission (NPC) analytical report (2000), the NPC found the literacy level to be far lower than some of the sub Saharan African countries. The report further revealed that $85 \%$ of the illiterate population was under 35yers of age, this is the productive age - group. Literacy rate according to urban and urban setting are $90 \%$ urban and $62 \%$ rural $(98 \%$ urban male, $79 \%$ urban female; $75 \%$ rural male $52 \%$ rural female) ESA, 2005. The MICS data (1999) as cited in ESA,(2005) gives a verdict of "no progress" in reducing either male or female illiteracy and the report recorded deterioration from the initials $57 \%$ to 49 $\%$ (FGN/UNICEF SITAN,2001).

Research Question 2: What is the trend of enrolment in respect to adult literacy centres in Nigeria? 
Table 1: Reflects the trend of enrolment in adult Literacy Centres in Nigeria from $2003-2008$

\begin{tabular}{lll}
\hline Year & Centres & Enrolment \\
\hline 2003 & 18,009 & $1,401,589$ \\
2004 & 17.372 & 1.285 .679 \\
2005 & 17,246 & 898.266 \\
2006 & 16,903 & $1.035,860$ \\
2007 & 16,511 & $1,858,871$ \\
2008 & 16,401 & $1,129,365$ \\
\hline
\end{tabular}

Source: Author's Computation from Education Sector Status Report. 2005, Adesina, 2005 and Nigeria: Digest of Education Statistics, 2011

Table 1 illustrates that the delivery structures of literacy and non-formal education show a total of 18,009 centres in $2003,17,372$ in 2004. 17,246 in 2005, 16,903 in $2006,16,511$ in 2007 and 16,401 in 2008 . These figures depict a decline of $8.1 \%$ between 2003 and 2008 . The issue of funding might be one of the major reasons for the decline in the number of these centres because the sustainability of the centres established hinged on funding as well as other management factors.

The enrolment pattern of learners likewise revealed unstable trend in these centres. Enrolment actually declined from a high of $1,858,871$ in 2007 to
$1,129,365$ in 2008 with a sharp decline of 898,266 in the year 2005.The declining number of centres and the subsequent decrease in learner enrolment in the provision of literacy in Nigeria are cause for concern if EFA goals must be achieved in Nigeria with the timeline set which is only three years away.

Research Question 3: What is the rate of female / male participation in adult literacy programme in Nigeria based on the sampled Zones/States?

Table 2 below reveals the rate of female and male participation in adult literacy programme in sampled Geo- Political Zones/Sampled states in Nigeria. 
Table 2: Gender Participation in Adult Literacy rates in \% sampled GeoPolitical Zones/Sampled states in Nigeria.

\begin{tabular}{lllllll}
\hline Zone & Women & \multicolumn{1}{c}{ Men } & $\%$ & W + M (Mean) & $\%$ \\
\hline South East (Enugu) & 26.038 & $(14.8 \%)$ & 17,488 & $(9.9 \%)$ & 24.7 \\
South West (Ondo) & 12.232 & $(6.9 \%)$ & 8.745 & $(5 \%)$ & 11.9 \\
North West (Sokoto) & 23.923 & $(13.5 \%)$ & 46.922 & $(26.6 \%)$ & 40.1 \\
North East (Borno) & 13.554 & $(7.7 \%)$ & 27.516 & $(15.6 \%)$ & 23.3 \\
\hline Total & 75.747 & & 100.671 & $100 \%$
\end{tabular}

Source: $\quad$ Author' Computation from Nigeria: Digest of Education statistics 2011.

The table reveals percentage rate of men and women participation in adult literacy education in selected four geo- political zones in Nigeria. All figures presented revealed that women participation is still far low when compared with that of their male counterpart in the northern zone of the country while the participation rate in the southern zone revealed marginal difference between men and women participation in the adult literacy class. The finding is similar to what is obtainable in the formal education setting.

Research Question 4: What is the adult Learners' perception on existing issues in the provision and management of adult literacy programmes in Nigeria?

Table 3: Frequencies and percentages of adult Learners' perception on existing issues in the provision and management of literacy programme in Nigeria

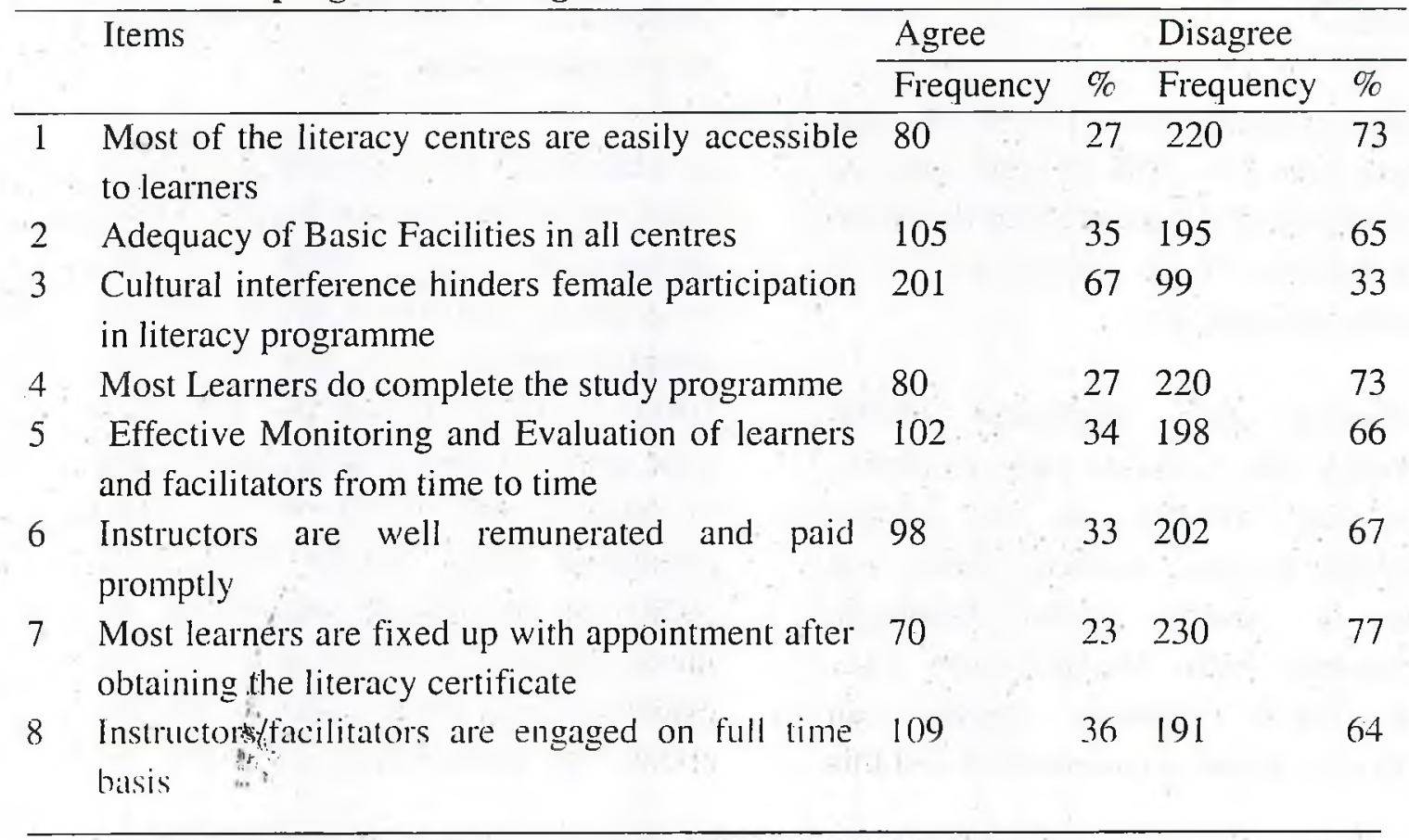


9 There are little or no individual practical $225 \quad 75 \quad 75$ activities during the literacy class

10 The Adult literacy centre receives regular funding $\quad 199 \quad 66 \quad 101 \quad 34$ support

From Table 3. response to the first question shows that 220 or $73 \%$ of the sampled adult participants disagree on the accessibility of learners to most of the literacy centres. This was likewise confirmed by SAPA document (1993) as cited in ESA (2005) reports a lack of access to literacy programme and Adult Education with as many as $46 \%$ of the sampled communities not having access to these programmes at the existing various centres. The finding further revealed that participation is restricted on grounds of non- functional programme offerings and long distance. This seems not encouraging enough for NMEC. This issue of access thus act as major constrain in the provision and management of literacy education in the country.

Their response to item 2 from the table shows that $195(65 \%)$ of the sampled participants of the programme disagreed that facilities in all literacy centres in Nigeria are adequate.

Confirming this, Adeboyeje, (1994) reported that facilities such as desks, fans, and libraries are not always available in these centres. Classes are held in shaddy school buildings, community halls. Market places e.t.c. The above situation implies un conducive learning environment and this affects the effective delivery of the programme. School facilities plays vital role in teaching and learning process. The optimal utilization of school basic facilities connotes the practice of using a school facility, for example, a building for as many purposes as possible, thereby reducing the number of buildings as well as the total cost of providing buildings in schools. Likewise the findings of this study support Kennedy (2001), and UNESCO, (1989). They discovered from their study that good facilities and conducive classroom had a major impact on learning. In addition, Moore, (1998) aptly summarizes the value of small class size. She says that students in these classes, "makes more rapid progress towards graduation. thereby minimize educational wastage".

In addition on the statement on item 3 , that Cultural interference hinders female participation in adult literacy programme, 201 (67\%) of the opinion sampled agreed with this statement. UNDP,(1997) confirmed that there is a wide gender disparity in the literacy rate in Nigeria with $62.5 \%$ of the male population being literate while only $39.5 \%$ of the female population are literate. Gender stereotyping is so much evidence in our modern society and this affects the participation of female for 
literacy class. Alele - Williams (1994) confirmed this by describing gender stereotyping as "hidden curriculum" which send out messages to girls to conform to role expectations. In most societies gender roles have shacked women to the floor, preventing them from participating in and benefiting from development efforts. The society as a whole thus suffers from the marginalization of half of its population, functioning only on half stream, as it were (Ohiri-Aniche, 2000).

$220(73 \%)$ of the sampled adult participants of the programme disagreed with the statement that "learners do complete the programme" Oyedeji (1998) sees efficiency as diligent application of economic use of resources, which has tremendous impact on effectiveness of any educational programmes. ESA, (2005) reported that the literacy programme efficiency seems not encouraging. Out of a total number of $1,142,966$ enrolled in $1996,814.143$ completed their respective programmes representing a dropout rate of $28.8 \%$ and completion rate of $71.2 \%$.of the number who completed, 625,363 $(57.4 \%)$ sat for the test and 467,662 were awarded certificates (CEA,2003) as cited in ESA, (2005).

On effective monitoring and evaluation, $198(66 \%)$ of the sampled opinions disagreed that there is effective monitoring and evaluation of learners and facilitators from time to time. Monitoring and evaluation is an area where many good programmes feel challenged. Resources are scarce and those that are available go into implementation. Obanya, (2008) stated that many of the literacy centres are neglected. There is no supervision and monitoring of all activities at these various centres. This therefore affects the efficiency of the progrmme. The NMEC mandate is to play an oversight role through their states' offices but the deplorable state of funding of the commission may be attributed to this weak monitoring and evaluation mechanism.

Likewise to the above, 202 (67\%) of the respondents perceived that the remuneration of their instructors is not attractive and was not paid promptly. This finding confirmed ESA, (2005) report and the UNESCO, Global Monitoring Report, (2010) that the stipend paid to instructors across the states is far below the actual National Benchmark prescribed at $\$ 7500$ per month per instructor and this has culminated non- commitment and dedication of these instructors as well as high attrition rate.

This had an adverse effect on quality of production in terms of provision and management of literacy programme in Nigeria. No wonder UNESCO and EFA Global Monitoring Report (2010) stated that despite the fact that facilitators have only basic level of literacy and not specific educational level should not be a justification for their poor 
remunerations. It is logical to say that without instructors the programme cannot be run.

$230(70 \%)$ of the sampled opinion perceived that most of the learners find it difficult to use the literacy certificate to get jobs. This justified Adesuyi, Bolarin, Obaniyi. and Uyanwa, (2007) findings on factors influencing adult learners" participation in literacy programmes in Nigeria that majority of these learners engaged in this programme basically to learn how to read and write and not using the certificate to seek for any office jobs.

Still on Table 3, statement item 8 , on the engagement of instructors /facilitators, $191(64 \%)$ of the respondents disagreed that none of the facilitator/ instructors of adult literacy programme are engaged on full time basis. NMEC, (2001) confirming this, reported that there are hardly any full time instructors and facilitators for literacy adult and nonformal education. They are mostly hired on part time basis while the instructor qualifications profile ranges from first school leaving certificate to teacher grade 11 certificates.
On practical activity/ interactive sessions during the adult literacy class, 225(75\%) of the respondents agreed that most of the learning is highly interactive and practical oriented. This finding corroborates Barret and Lyons.(1998) who argues that collective participation of learners could enhance their pattern of expressing ideas, opinions. and intentions within and outside the classroom setting. This will no doubt be of added advantage to these adult learners in facilitating their performance in the programme.

On adequate funding of the programme, $199(66 \%)$ of the sampled opinion agreed that the adult literacy centres have not been receiving regular funding support. Adequate funding support by Federal, State and Local Governments is fundamental as regards effective provision of any education programme in Nigeria as opined by in PTTE report (2011) under the chairmanship of Professor Pai Obanya.

\section{Research Hypothesis}

There is no significant difference between the perception of male and female recipients of this programme 
Table 4: Difference between male and female adult learners' perception on issues of provision and management of adult literacy programme in Nigeria

\begin{tabular}{lllllllll}
\hline Group & $\mathrm{N}$ & $\mathrm{X}$ & $\mathrm{SD}$ & Df & t.cal. & t. critical & Probability level & Remark \\
\hline Male & 150 & 36.42 & 7.68 & 298 & 0.015 & 1.86 & 0.05 & Ns \\
\cline { 1 - 5 } Female & 150 & 40.48 & 4.89 & & & & & \\
\hline \multicolumn{7}{c}{ NS = Not Significant. }
\end{tabular}

Table 4 reveals the perception of male and female adult learners perception on issues of provision and management of adult literacy programme in Nigeria. The means representing male and female perceptions are 36.42 and 41.48 respectively. However, the t. calculated value of 0.015 is lower than the critical value of $t$ which is 1.86 . The finding revealed that there is no significant difference in male and female adults' perception on issues in the provision and management of adult literacy programme in Nigeria. The above findings run contrary to Ijaiya (1999) whose finding revealed that male perception of issues is much differs from their female counterpart. Nevertheless this finding confirm Obanya (2002) and UNESCO(2010) that gender seems not to have much influence on students prediction of learning situation since all learners are subjected to same instructional conditions.

\section{Major Findings}

- The literacy rate in Nigeria is still far lower than some of the subSaharan African countries

- $\quad$ Nigeria illiteracy population was found to be under 35 years of age
- The literacy rate in the urban and rural setting is $90 \%$ and $62 \%$ respectively

- The enrolment trend in adult literacy centres in Nigeria has not been stable. Analysis reveals a fluctuating trend in enrolment within the year under study

- Finding likewise reveal that gender participation in adult literacy classes varies according to geo- political zones of the federation with south east having the highest participation rate of women in adult literacy classes

- Access to existing centres has been an inhibiting factor towards effective participation of willing learners

- Facilities in most of the centres were reported to have been inadequate

- Gender stereotyping has been another inhibiting factor preventing access to adult literacy programme in the northern zones of the federation

- The efficiency of literacy programme in Nigeria seems not encouraging due to high dropout rate among learners 
- $\quad$ The study likewise reveals that most of the Instructors/ facilitatoss were not adequately remunerated

- Lastly, the perceptions of both male and female learners sampled on issues around the management of adult literacy programme in Nigeria seems similar since no significant differences was established from the calculated $\mathrm{T}$ value

\section{Recommendations}

Based on the major findings, the following recommendations are hereby made:

- There is need for effective supervision and monitoring of all adult literacy centres in Nigeria

- More awareness and sensitization should be put in place for people to buy into $2^{\text {nd }}$ chance education programme through adult literacy programme

- Government should addressed the issue of poor remunerations of all instructors and facilitators so as to ensure more commitment and dedication on the part of these facilitators

- National EMIS data should captured periodic data on the state of adult literacy programmes in Nigeria so as to have an updated data in ${ }^{\circ}$ establishing trend as well as usage for planning purposes

\section{Conclusion}

Based on the findings of this study, it implies that for realization of MDGs and EFA goals in Nigeria all the following identified issues in the management and provision of adult literacy programmes need to be addressed because it is only a man that can distinguish between truth and falsehood is really free to choose and participate actively in any national development programmes. This makes the role of education becomes crucial in enlightening and informing societal members in making wise choices both for their individual welfare and for the welfare of the state. Therefore it is important to remind our policy makers that the Education for All (EFA) agenda is incomplete without adult literacy so that by the year 2015, when all countries globally will be counting the blessings of EFA, Nigeria as a country will not be left out.

\section{Implications for planning}

- The adoption of SWOT analysis will go a long way for effective planning and implementation of adult literacy programme whereby the existing strengths, weakenesses, opportunities and threats are diagnosed towards ensuring a successful implementation of the programme in Nigeria.

For effective implementation of any programme, it is important to invest in on- going feedbacks and evaluation 
mechanisms, data systematization and strategic research. With constant monitoring, a needed assessment survey of target beneficiaries should be conducted to inform further programme planning of adult literacy programme in the country.

- Also there is need for all the facilitators to receive substantial training as well as having on-going opportunities for exchange with other facilitators to building their capacity so as to make them more efficient and effective. This necessitates the conduction of Training Needs Assessments (TNA) by all State Agency for Mass Education (SAME) which will further inform policy decisions on capacity building of all the instructors/facilitators.

- The need for timely, valid and reliable data is evident across all sub- sectors of education. The challenge of having authenticated data as regards enrolment, facilitators/instructors, classroom spaces in all centres, and infrastructure required has affected effective planning for the provision of literacy programme. Therefore a base study to provide data disaggregated by gender, states, age groups, educational attainment levels, urban/ rural dimensions, e.t.c. is an essential step that must be undertaken. This will assist in having a clear picture of who is being targeted. where and for what purpose.

- Public Expenditure Review is very necessary for all programmes. This has to do with the analyzing public expenditures and the impacts of different interventions on sustainable development. It will assist in proper linking of programme policy with planning, budgeting as well as its implementation.

\section{References}

Adesina, S. (2005). Growth without development: Nigeria education experience. Abeokuta. Yemab Press

Adesuyi, G. B.; Bolarin, O.; Obaniyi. K. S.; Uyanwa, F. A. (2007). Factors influencing literacy programmes in Atiba Local Government Area of Oyo State in Nigeria. In journal of researches in agricultural sciences, 4: $75-81$

Action -aid, (2008). Action Aid, Nigeria calls for government to invest in adult literacy. Retrieved from http://wwwactionaidusa.org/news/re lated/education/nigeria egben. July. $24^{\text {th }}$.

Alele-Williams, G. (1986) "Edlucation of Women for National development" A paper delivered at workshop on women's education in Nigeria, Lagos

Adeboyeje, R. A. (1999): Management of school physical facilities. Ibadan. Fountain publication.

Barret and Lyons (1998). Social Groups and work performance. London; Heinemann Press. 
Burchfield, S.; Hua, H.; Baral, D. and Rocha, V. (2002). A longititudinal study of the effect of integrated literacy and basic education programs on the participation of women in social and economic development in Bolivia. USAID/ World Education Inc.

Cameron, J. (2005). Commissioned study of Economics Benefits of Increased literacy, for EFA, GMR. 2006

David and Richard S. (2006) ICT and Learning. Supporting out-of-school Youth and Adults. OECD

Federal Ministry of Education, (2011). Nigeria: Digest of education statistics. Abuja: Author

Federal Ministry of Education (2005). Education sector status report (2005) Abuja: Author

Federal Republic of Nigeria (2006). National Policy on Education. Lagos: NERDC Press

Federal Republic of Nigeria (2011). Presidential Task Team on Education (PTTE) Report. Abuja

Ijaiya, N.Y.S. (1999). 'Effect of overcrowded classrooms on teacher - students' interactions. In Ilorin Journal of Education, 19: $1-11$

Kennedy, M. (2001): Into thin air. American schools and University. 73 (6): 32.
Maddox, B. (2008). What good is literacy? Insights and implications of the capabilities approach. Journal of Human Development. 9 (2): 185-206.

Midgley. G. (2003). System Thinking. London: Sage

National Population Commission (NPC) (2000). Nigeria demographic and health survey 1999. Abuja: Author.

Noboh. Sebagen. (2012). Eradicating illiteracy in Nigeria. Retrieved from

http://nigeriablueprintnewspaper.ht ml.org July $24^{\text {th }}$.

NMEC (2001) Statistic Digest. Abuja: Author FGN/UNICEF

NCAL and ILI, (2006). www.literacy.org. Retrieved 7/6 2007-08-02 Wikipedia, the free encyclopedia. htm. Retrieved 7/6 2007

Moore, D. (1998): Improve your school atmosphere. In joumal on school planning management. 37 (10): 18.

Obanya Pai (2002). Revitalizing Education in Africa. Stirling-Horden Press. Ibadan

Obanya Pai (2008). Thinking and Talking Education Evans Brothers Ltd. Ibadan 
Ohiri-Aniche, C. (2000). Gender issues in Education: In the state of education in Nigeria. UNESCO, Abuja.

Oxenham, J. (2008). Effective Literacy Programmes: Options for Policy Makers. Paris. UNESCO International Institute for Educational Planning. (Fundamentals of Educational Planning) pp.9l

Oyedeji, N. B. (1998). Management in education: principles and practice. Lagos: ARAS publishers.

Osuji.S.N.(2006). Education for fullness: The role of adult education in Nigeria in the $21^{\text {st }}$ century. In journal of social science. 12(1) pp49-54

Scultz,T.(1993)"Returns to women 's education '.In Kings ,E.H and Hill, M.A (eds)Women's education in developing countries; Barriers, benefits and Policies,. Baltimore and London: The John Hopkins University Press.
UNDP, (1997) Nigerian Human Development Report 1996. Lagos, Nigeria.

UNDP, (2005). Manual on Human rights, Good Governance and the Rule of Law: Role and Relevance of the Human Rights Defender of Armenia. Accessed on http://www.europeanombudsmen .org/goodadministration/armenia. pdf

Ukeje B. O. (1978), Education for social reconstruction. Macmillan. London.

UNESCO, EFA (2005). Writing the wrongs. International Benchmarks an adult literacy.

UNESCO, (2009). EFA Global Monitoring Report. UNESCO

UNESCO Report (1989). Facilities Utilization in higher Education. UNESCO.

UNESCO, (2010). EFA Global Monitoring Report. UNESCO

UNICEF (2001). L'éducation pour tons - Dossier'd Information 